\title{
INVESTIGATING THE WATER ABSORBANCE OF DIFFERENT INSULATION MATERIALS
}

\author{
Bence LOVAS \\ University of Debrecen, Faculty of Engineering, Department of Building Services and Building Engineering, \\ Debrecen, Hungary, bence.lovas@outlook.com
}

\begin{abstract}
In this work, the moisture absorbance of 6 different building insulation materials are inspected in a laboratory environment. After being dried to a constant weight, the materials were exposed to five different, equally distributed, relative humidity environments, ranging from $0 \%$ to $100 \%$. At each chosen relative humidity range the weight of absorbed water content was measured. Then the results were analysed. The insulation materials were then ranked using results from this and the author's previous work.
\end{abstract}

Keywords: insulation, humidity, ranking, water content.

\section{The effect of moisture on insulation materials}

The overwhelming majority of building materials and building insulation materials have high porosity structures. The summed surface area of these pores tends to be quite large. This could play a major role in the moisture absorbance of these materials.

Before we begin the inspections, it is very important to define the following concepts:

The adsorption is the adhesion of molecules from fluid phase (gas or liquid) to a solid surface.

The moisture sorption property of the materials can be best described with the sorption isotherm. The interaction between the porous material and the environment it is in can happen in two directions:

- If the $p_{f}$ partial pressure is greater on the surface of the material than the $\mathrm{p}_{\mathrm{g}}$ partial pressure of the surrounding air, then desorption occurs which means the material is drying

- If the pf partial pressure is smaller on the surface of the material than the $\mathrm{p}_{\mathrm{g}}$ partial pressure of the surrounding air, then adsorption has started

\section{Standard related to the laboratory measurements}

During this work I have followed the regulations found in the EU standard MSZ EN ISO 12571:2013 which is an international standard. However, it is also in effect in Hungary. This standard is intended to regulate the processes by which the sorption isotherms of building materials and other construction industry products are determined.

The examined material samples that are under $300 \mathrm{~kg} / \mathrm{m}^{3}$ when dried to a constant mass, should have at least $100 \mathrm{~mm} \times 100 \mathrm{~mm}$ surface area. To reach the dried constant mass faster it is permissible to cut the samples into smaller pieces, provided it can be proven that cutting up the material samples will not affect the measurement results. [2]

It is required to measure at least 3 specimens from each one of the materials

\subsection{Method for determining the sorption isotherms}

The material samples are dried to a constant dried mass. After that, at least 4 different relative humidity ranges have to be chosen in which the materials will be humidified. In the test chambers the chosen relative humidity ranges should be 
chosen in such a way that they are equally distributed between $0 \%$ and $100 \%$ relative humidity. The moisture content of the test specimens should be measured after equilibrium has been reached with the test environment. The moisture content is the difference in mass between the constant dried mass and the mass of the sample after the humidification process.

After the measurements are done in all of the chosen relative humidity measurement ranges, the adsorption isotherm for the material can be determined. [3-5]

\subsection{Instruments required for the measure- ments}

In accordance with the standard mentioned above the following instruments are to be used during the lab processes:

- measuring container (hydrophobic),

- a scale that has a precision of $\pm 0,01 \%$,

- a drying oven in accordance with the ISO 12570 standard,

- a climatic chamber which has a precision in setting the relative humidity inside the chamber of $\pm 5 \%$, while maintaining a range of $\pm 2 \mathrm{~K}$ in temperature.

Due to the materials used in this study, a measuring container was not necessary.

\section{Lab measurements}

\subsection{Material samples}

During measurements the following 6 building insulation materials were used:

- aerogel

- rockwool

- foamglas

- PUR

- special surface PS

- graphite EPS

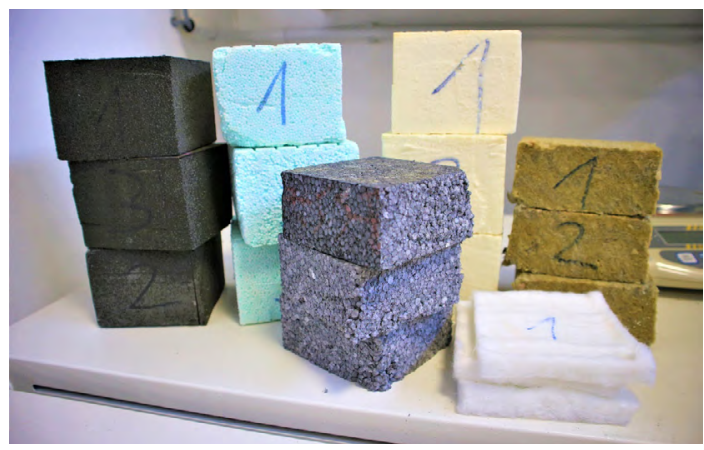

Figure 1. Material samples in the lab numbered
Each material was cut into a $100 \mathrm{~mm} \times 100 \mathrm{~mm}$ slab with a varying height depending on the original height of the acquired materials. The samples were numbered from 1-3 for easier identification (Figure 1.)

\subsection{The process of the measurements}

The samples were dried for 24 hours in a Venticell 111 drying oven. After that the constant dried mass of the materials were measured on a scale with an accuracy of a thousandth of a gram.

As a next step the samples were humidified in a Climacell 111 climatic chamber with a 24-hour cycle time at the chosen relative humidity ranges. Although the standard requires only 4 relative humidity ranges for measurements, for improved results chose 5 relative humidity ranges. These were chosen in accordance with the standard mostly equally distributed from $0 \%-100 \%$ as follows:

\section{- $30 \%, 45 \%, 60 \%, 75 \%, 95 \%$}

After each humidification phase the weight of the materials were measured, yielding 3 results for the 3 samples of each material at all the selected relative humidity ranges. With these data the absorbed moisture content of each material was calculated using the following formula from the standard:

$$
\omega_{A D}=\frac{m_{n}-m_{S Z}}{m_{S Z}} \times 100
$$

The average of the samples was taken for the graph of the sorption isotherms. Also, the deviation from the average was determined for each measurement range.

In this way the sorption isotherms for each material could be depicted as a line graph in Excel. The deviation from average values is represented at each marker as an error bar.

\subsection{Measurement results}

The sorption isotherm for each insulation material was plotted in their own graph. However, for better comparison, the results have also been plotted in one diagram as shown on the Figure 2. Looking at the graphs from a building physics standpoint we can determine that the foamglas performed the most favourably. According to the measurements this material did not absorb any water. On Figure 2. it is seen marked with the grey colour. The graph for this material shows only horizontal characteristics. There is a slight uptrend at the $95 \%$ relative humidity range. Al- 


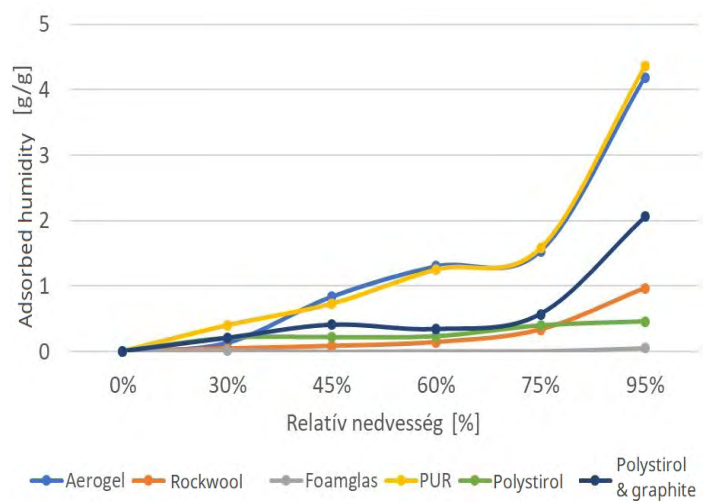

Figure 2. Adsorption isotherms combined in one diagram

though it is most likely only a surface condensation, not actually the material absorbing moisture.

The rockwool performed almost as well, in the lower humidity ranges, however it shows more uptrend in the higher ranges than the foamglas. With this material, because of the fibrous structure, we were expecting a much steeper climb before the measurements. After the isotherm was plotted we made the assumption that it had a previously unknown hydrophobic coating. With this coating the characteristics of this graph is quite favourable even with the slight climb at the higher humidity ranges.

The third one was the polystirol with the specially formed surface regarding the building physics properties. However the characteristics of the isotherm for this material differs from the previous ones: the scale is mostly the same. In the $0-75 \%$ relative humidity range the isotherm for this material is above the rockwool. After $75 \%$ but before $95 \%$ the two isotherms cross each other and the polystirol performs better in this higher humidity range.

The fourth, the polystirol with mixed-in graphite powder, performed the best. If we are examining its properties from a building physics standpoint it's still one of the better ones from the measured materials. In the $0 \%-75 \%$ relative humidity ranges its graph follows a similar path both in scale and characteristics as the previous ones. However, in the $95 \%$ relative humidity range there is a steeper climb in comparison with the previous materials. This is something that should be kept in mind when applying this insulation.

In these measurements, the aerogel proved to be one of the worst from the samples. However, the heat insulation properties are outstanding for this insulation material, the moisture absorption is quite significant. At the $30 \%$ relative humidity range it performed relatively well. After this range there is a steep climb in the characteristics of its graph with the increase of the humidity in the environment. At $60 \%$ humidity range it has already exceeded the $1 \mathrm{~g} / \mathrm{g} \%$ value which the previous ones, except for the graphite one, didn't even reach at the highest humidity range. Because the moisture absorbance starts at a relatively low humidity range this material is not very desirable from a building physics stand-point. As this could significantly influence the thermal properties of the material this could be quite disadvantageous. Also, it could lead to other problems such as capillary condensation and structural deterioration.

Lastly, the polyurethane performed the worst regarding moisture absorption during these measurements. Unlike the rockwool we expected much better results from this material as this is supposed to be a closed cell insulation material, which in itself, should obstruct the absorbance of moisture by the material. In Figure 2. it can be seen that the adsorption isotherm of this material follows a similar characteristic to the aerogel, still in most of the measurement ranges, the absorbed moisture content is above that. From the examined materials this proves to be the least desirable from a building physics viewpoint.

\section{Conclusions}

During my work I have determined the adsorption isotherms of 6 different insulation materials. These isotherms could be used in simulation software when investigating the vapour properties of these materials. This simulation software can give better, more precise results when the data used in the simulation are based on actual measurements.

\section{References}

[1] Fekete I. (ed.): Épületfizika kézikönyv. (Handbook of Building Physics), Műszaki Könyvkiadó, Budapest, 1985.

[2] MSZ EN ISO 12571: Építési anyagok és termékek hö- és nedvességtechnikai viselkedése. A higroszkopikus szorpciós tulajdonságok meghatározása. 2013

[3] Jirickova M., Cerny R., Rovnanikova P.: Measurement of Moisture Storage Parameters of Building Materials. Acta Polytechnica 43/2. (2002) 39-43.

[4] Á. Lakatos: Investigation of water sorption properties of different insulating materials In: Proceed- 
ings in Advanced Research in Scientific Areas. The 1st Virtual International Conference. Zilina, Slovakia, 2012.12.03-2012.12.07. (Eds.: Mokryš M., Lieskovský A.) Zilina EDIS, 2012. 1827-1831.

[5] A. Lakatos A: Method for the determination of sorption isotherms of materials demonstrated through soil samples. International Review of Applied Sciences and Engineering 2/2. (2011) 117-121.

https://doi.org/10.1556/IRASE.2.2011.2.7 